\title{
PENGARUH FINANCIAL LITERACY DAN FINANCIAL ATTITUDE TERHADAP FINANCIAL SATISFACTION
}

\author{
Natasya Putri Himawan dan Hendra Wiyanto \\ Program Studi Manajemen Fakultas Ekonomi dan Bisnis Universitas Tarumanagara, Jakarta \\ Email: natasya.115170154@stu.untar.ac.id
}

\begin{abstract}
The purpose of this research is to analyze and find out the impacts of financial literacy and financial attitude towards financial satisfaction. This research uses primary data by spreading online google form questionaire, with non-probability sampling. The samples used in the research are Go-Pay users based in West Jakarta. There are 264 respondents in total, but the usable data was as many as 240 respondents. The data analysis technique used is Structural Equation Modeling (SEM) with Smart-PLS program version 3.3.2. The result of this study show that there is a positive positive impacts between financial literacy and financial attitude towards financial satisfaction of Go-Pay user in West Jakarta.
\end{abstract}

Keywords: Financial Literacy, Financial Attitude, Financial Satisfaction.

Abstrak: Tujuan dari penelitian ini adalah untuk menganalisa dan mengetahui pengaruh dari financial literacy dan financial attitude terhadap financial satisfaction. Penelitian ini menggunakan data primer melalui proses pengumpulan data dengan cara membagikan kuisioner secara online menggunakan google form serta menggunakan metode non-probability sampling. Sampel dalam penelitian ini adalah pengguna Go-Pay yang berdomisili di Jakarta Barat. Data yang berhasil dikumpulkan berjumlah 264 responden, namun data yang dapat digunakan adalah sebanyak 240 responden. Teknik analisis data yang digunakan adalah Structural Equation Modeling dengan program Smart-PLS versi 3.3.2. Hasil dari penelitian ini menunjukkan bahwa terdapat pengaruh positif antara financial literacy dan financial attitude terhadap financial satisfaction pada pengguna Go-Pay di Jakarta Barat.

Kata kunci: Literasi Keuangan, Sikap Keuangan, Kepuasan Keuangan.

\section{LATAR BELAKANG}

Perkembangan teknologi seperti zaman sekarang ini bertumbuh semakin cepat, dari hari ke hari, bulan ke bulan, hingga tahun kedepannya. Semakin canggihnya teknologi, pada zaman sekarang masyarakat lebih memilih untuk menggunakan sistem pembayaran dengan elektronik dari pada menggunakan transaksi dengan cash, karena kemudahan dari pembayaran elektronik yang ditawarkan. Seiring berjalannya waktu, dengan munculnya perkembangan uang elektronik ini maka masyarakat perlu lebih bijak dalam merencanakan dan mengelola keuangannya. Karena dengan masyarakat bijak dalam mengelola keuangannya, itu akan membuat masyarakat dalam mencapai keputusan keuangan yang lebih baik sehingga merasa puas dengan keuangan yang dimiliki. Kemudian, hal ini dapat dikaitkan dengan tingkat kepuasan keuangan masyarakat.

Kepuasan merupakan suatu bentuk kebahagiaan yang dicapai oleh seseorang dengan hasil usahanya (Arifin, 2018). Salah satu bentuk kebahagiaan adalah melalui pencapaian financial satisfaction. Financial satisfaction bersumber dari individu seseorang yang dikaitkan 
dengan cara bagaimana orang tersebut dapat mengelola pendapatannya guna memenuhi kebutuhan finansialnya.

Financial satisfaction merupakan kepuasan yang dirasakan oleh seseorang berdasarkan aspek situasi keuangan yang mereka alami (Sahi, 2013). Seorang individu akan dikatakan bahagia dan puas jika kondisi keuangan mereka baik. Financial satisfaction berawal dari bentuk pada perilaku seorang individu yang berkaitan dengan bagaimana para individu mengelola pendapatan keuangannya. Kebutuhan finansial dikatakan berhasil jika seseorang mampu memenuhi semua kebutuhannya dalam jangka pendek maupun jangka panjang tanpa adanya kesulitan ataupun kekurangan.

Terdapat beberapa variabel yang dapat mempengaruhi financial satisfaction salah satunya yaitu financial literacy. Berdasarkan hasil penelitian yang telah dilakukan oleh Henager dan Anong (2014) menunjukkan bahwa adanya pengaruh yang positif antara financial literacy terhadap financial satisfaction, seseorang yang memiliki financial literacy yang tinggi maka akan memiliki kemungkinan yang tinggi juga akan mencapai financial satisfaction.

Kemudian, variabel lain yang dapat mempengaruhi financial satisfaction adalah financial attitude. Chandra dan Memarista (2015) mengungkapkan bahwa adanya pengaruh yang positif antara financial attitude terhadap financial satisfaction. Salah satu dari financial attitude yang baik yaitu seperti menyisihkan sebagian uang yang dimiliki untuk ditabung, maka itu akan memiliki dampak yang positif bagi keuangan pribadi sehingga dapat meningkatkan financial satisfaction.

Berdasarkan permasalahan di atas, dapat disimpulkan bahwa tujuan dari penelitian ini adalah untuk membuktikan apakah financial literacy dan financial attitude terdapat pengaruh yang positif terhadap financial satisfaction pada pengguna Go-Pay yang berdomisili di Jakarta Barat.

\section{KAJIAN TEORI}

Penelitian ini mengacu pada Theory of Planned Behavior yang didasari oleh asumsiasumsi pada manusia yang biasanya berperilaku dengan cara yang masuk akal, seperti mempertimbangkan atau memperhitungan informasi yang ada secara eksplisit ataupun implisit (Ajzen, 2005). Theory of Planned Behavior bertujuan untuk memprediksi perilaku seorang individu secara lebih spesifik (Ajzen, 1985). Teori ini memberikan gambaran konseptual mengenai factor-faktor bagaimana cara menangani perilaku-perilaku manusia.

\section{Financial Satisfaction}

Menurut Hira \& Mugenda (1998) financial satisfaction merupakan salah satu komponen kehidupan yang ditandai dengan kecukupan aset keuangan. Seseorang yang memiliki financial satisfaction yang baik adalah seseorang yang dapat memenuhi kondisi keuangannya saat ini (Praag \& Carbonell, 2002). Semakin puas seseorang terhadap kondisi keuangan pribadinya maka individu tersebut akan semakin merasa puas dan bahagia.

\section{Financial Literacy}

Garman dan Forque (2010) mengungkapkan bahwa financial literacy merupakan pengetahuan yang cukup tentang prinsip, fakta, konsep, dan teknologi yang mendasari sebagai dasar cerdas dalam menggunakan uang. Financial literacy juga diartikan sebagai komponen sumber daya manusia yang berfungsi untuk meningkatkan kesejahteraan finansial (Huston, 2010). 


\section{Financial Attitude}

Selanjutnya menurut Pankow (2012) financial attitude didefinisikan sebagai keadaan penilaian tentang keuangan, pikiran dan pendapat. Financial attitude juga merupakan sebuah tendensi psikologis yang yang diekspresikan saat mengevaluasi praktik manajemen keuangan oleh tingkat kesepakatannya (Jodi \& Phyllis, 1998).

\section{Kaitan antara Financial Literacy dengan Financial Satisfaction}

Berdasarkan hasil penelitian yang dilakukan oleh Henager dan Anong (2014) menyatakan bahwa adanya pengaruh yang positif antara financial literacy terhadap financial satisfaction, seseorang yang memiliki financial literacy yang tinggi maka akan memiliki kemungkinan yang tinggi juga akan mencapai financial satisfaction.

\section{Kaitan antara Financial Attitude dengan Financial Satisfaction}

Pada penelitian yang dilakukan oleh Arifin (2018) menunjukkan bahwa adanya pengaruh yang positif antara financial attitude terhadap financial satisfaction. Jika seorang individu mempunyai financial attitude yang baik dalam mengelola keuangannya, maka akan memperoleh financial satisfaction terhadap seseorang meningkat.

Berdasarkan uraian kaitan antar variabel diatas, maka terbentuk kerangka pemikiran sebagai berikut:

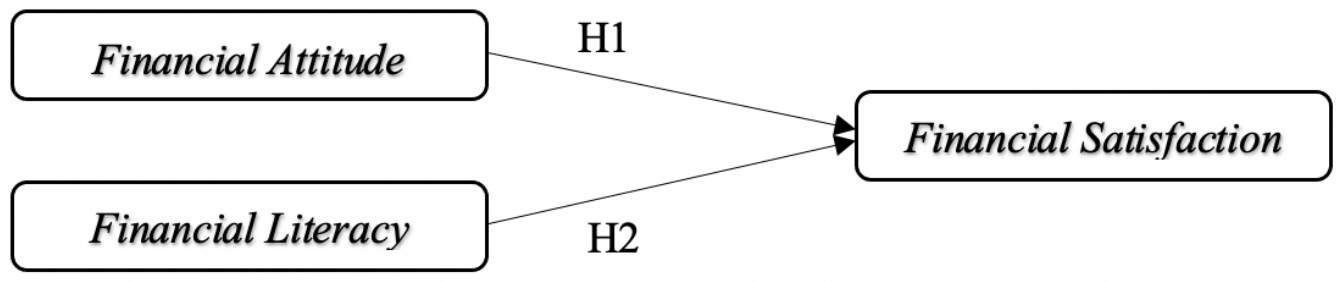

\section{Gambar 1 \\ Kerangka Pemikiran}

H1 : Terdapat pengaruh positif financial attitude terhadap financial satisfaction.

$\mathrm{H} 2$ : Terdapat pengaruh positif financial literacy terhadap financial satisfaction.

\section{METODOLOGI}

Penelitian ini menggunakan desain penelitian deskriptif dengan metode kuantitatif. Populasi dalam penelitian ini adalah seluruh pengguna Go-Pay yang berdomisili di Jakarta Barat. Penelitian ini melibatkan 264 responden, namun ada beberapa dari jumlah responden yang tidak memenuhi kriteria yang telah ditentukan dalam screening question pada kuisioner, maka responden yang dapat digunakan adalah sebanyak 240 responden. Metode pengambilan sampel dalam penelitian ini adalah metode non-probability sampling dengan teknik purposive sampling. Penelitian ini menggunakan data primer yang diperoleh dari responden melalui kuisioner yang disebarkan secara online melalui google form.

Berdasarkan data yang telah terkumpul, diketahui bahwa didapatkan sebanyak 240 orang $(91 \%)$ berdomisili di Jakarta Barat dan sisanya sebanyak 24 orang atau sebesar $9 \%$ tidak berdomisili di Jakarta Barat. Dalam penelitian ini mayoritas responden adalah berjenis kelamin perempuan dengan jumlah sebanyak 137 orang $(57,1 \%)$ dan sisanya laki-laki berjumlah 103 orang $(42.9 \%)$. Dikelompokkan berdasarkan usia, didapatkan bahwa responden yang berusia 
dibawah 20 tahun terdapat sebanyak 54 orang (22.5\%), usia 21 tahun sampai dengan 30 tahun terdapat sebanyak 181 orang $(75.4 \%)$, usia 31 tahun sampai dengan 40 tahun terdapat sebanyak 2 orang $(0.8 \%)$, usia diatas 40 tahun terdapat sebanyak 3 orang $(1.2 \%)$. Berdasarkan pendidikan terakhir, didapatkan bahwa terdapat 153 orang $(63.7 \%)$ yang tamat pendidikan SMA/SMK, terdapat 3 orang $(1.2 \%)$ yang tamat pendidikan D3, terdapat 82 orang $(34.2 \%)$ yang tamat pendidikan S1, lalu terdapat 2 orang $(0.8 \%)$ yang tamat pendidikan S2.

Selanjutnya berdasarkan pekerjaan, didapatkan sebanyak 192 orang (80\%) dengan pekerjaan sebagai pelajar atau mahasiswa, terdapat sebanyak 23 orang (9.6\%) dengan pekerjaan sebagai karyawan swasta atau negeri, terdapat sebanyak 20 orang $(8.3 \%)$ dengan pekerjaan sebagai wirausaha, terdapat sebanyak 3 orang (1.2\%) dengan pekerjaan sebagai ibu rumah tangga terdapat dan lainnya yakni terdapat 1 orang $(0.4 \%)$ sebagai trader dan 1 orang $(0.4 \%)$ juga sebagai freelancer.

\section{HASIL ANALISIS DATA}

1. Uji Validitas

\section{Convergent Validity}

Tabel 1. Hasil Analisis Average Variance Extracted (AVE)

\begin{tabular}{|c|c|}
\hline Variabel & Average Variance Extracted \\
\hline Financial Literacy & 0,523 \\
\hline Financial Attitude & 0,519 \\
\hline Financial Satisfaction & 0,516 \\
\hline
\end{tabular}

Tabel 1 menunjukkan nilai Average Variance Extracted (AVE) dari setiap variabel yang diteliti dan menunjukkan nilai koefisien lebih besar dari 0,5. Sehingga dapat disimpulkan bahwa penelitian ini memenuhi salah satu kriteria dari convergent validity.

Tabel 2. Hasil Nilai Loading Factor

\begin{tabular}{|c|c|c|c|}
\hline Indikator & $\begin{array}{c}\text { Financial } \\
\text { Literacy }\end{array}$ & $\begin{array}{c}\text { Financial } \\
\text { Attitude }\end{array}$ & $\begin{array}{c}\text { Financial } \\
\text { Satisfaction }\end{array}$ \\
\hline FL1 & 0,750 & & \\
\hline FL3 & 0,698 & & \\
\hline FL4 & 0,784 & & \\
\hline FL5 & 0,567 & & \\
\hline FL6 & 0,794 & & \\
\hline FA1 & & 0,745 & \\
\hline FA2 & & 0,649 & \\
\hline FA3 & & 0,796 & 0,618 \\
\hline FA4 & & 0,684 & 0,642 \\
\hline FS1 & & & 0,744 \\
\hline FS2 & & & \\
\hline FS3 & & & \\
\hline
\end{tabular}




\begin{tabular}{|l|l|l|l|}
\hline FS4 & & & 0,768 \\
\hline FS5 & & & 0,766 \\
\hline FS6 & & & 0,823 \\
\hline FS7 & & & 0,694 \\
\hline FS8 & & & 0,664 \\
\hline
\end{tabular}

Berdasarkan tabel 2 di atas, maka dapat diketahui bahwa seluruh indikator pada variabel dependen maupun independen menunjukkan nilai di atas 0,5 (loading factor $>0,5$ ) yang artinya sudah memenuhi kriteria dari convergent validity. Maka dapat disimpulkan bahwa seluruh indikator dapat digunakan dalam penelitian ini.

\section{Discriminant Validity}

Tabel 3. Hasil Nilai Cross Loading

\begin{tabular}{|c|c|c|c|}
\hline Indikator & Financial Attitude & Financial Literacy & Financial Satisfaction \\
\hline FA1 & 0,745 & 0,402 & 0,450 \\
\hline FA2 & 0,649 & 0,247 & 0,361 \\
\hline FA3 & 0,796 & 0,324 & 0,415 \\
\hline FA4 & 0,684 & 0,655 & 0,498 \\
\hline FL1 & 0,449 & 0,750 & 0,508 \\
\hline FL3 & 0,280 & 0,698 & 0,456 \\
\hline FL4 & 0,442 & 0,784 & 0,512 \\
\hline FL5 & 0,476 & 0,567 & 0,490 \\
\hline FL6 & 0,462 & 0,794 & 0,566 \\
\hline FS1 & 0,324 & 0,397 & 0,618 \\
\hline FS2 & 0,346 & 0,377 & 0,642 \\
\hline FS3 & 0,417 & 0,551 & 0,744 \\
\hline FS4 & 0,556 & 0,530 & 0,768 \\
\hline FS5 & 0,510 & 0,553 & 0,766 \\
\hline FS6 & 0,411 & 0,628 & 0,823 \\
\hline FS7 & 0,486 & 0,392 & 0,694 \\
\hline FS8 & 0,410 & 0,556 & 0,664 \\
\hline & & & \\
\hline
\end{tabular}

Pada tabel 3. dapat dilihat bahwa nilai cross loading yang ada di setiap indikator pada variabel menunjukkan nilai yang lebih besar dari nilai cross loading lainnya. Maka seluruh konstruk variabel dalam penelitian ini dinyatakan telah lolos dan memenuhi kriteria pengujian cross loading. 
Tabel 4. Hasil Analisis Fornell Larcker

\begin{tabular}{|c|c|c|c|}
\hline Variabel & $\begin{array}{c}\text { Financial } \\
\text { Attitude }\end{array}$ & $\begin{array}{c}\text { Financial } \\
\text { Literacy }\end{array}$ & $\begin{array}{c}\text { Financial } \\
\text { Satisfaction }\end{array}$ \\
\hline $\begin{array}{c}\text { Financial } \\
\text { Attitude }\end{array}$ & 0,720 & & \\
\hline $\begin{array}{c}\text { Financial } \\
\text { Literacy }\end{array}$ & 0,589 & 0,723 & \\
\hline $\begin{array}{c}\text { Financial } \\
\text { Satisfaction }\end{array}$ & 0,608 & 0,705 & 0,718 \\
\hline
\end{tabular}

Tabel 4. menunjukkan nilai akar kuadrat AVE yang ada di setiap konstruk variabel menghasilkan nilai yang lebih besar daripada korelasi antar variabel. Hal tersebut membuktikan bahwa kriteria dari analisis fornell larcker pada discriminant validity terpenuhi.

\section{Uji Reliabilitas}

Analisis uji reliabilitas dilakukan dengan melihat dari nilai Cronbach's Alpha dan Composite Reliability yang ditampilkan pada tabel 3 di bawah ini.

Tabel 5. Hasil Nilai Cronbach's Alpha dan Composite Reliability

\begin{tabular}{|c|c|c|}
\hline Variabel & Cronbach's Alpha & Composite Reliability \\
\hline Financial Attitude & 0,691 & 0,811 \\
\hline Financial Literacy & 0,766 & 0,844 \\
\hline Financial Satisfaction & 0,864 & 0,894 \\
\hline
\end{tabular}

Berdasarkan tabel 5. di atas, seluruh indikator yang ada dalam penelitian ini dikatakan memenuhi kriteria uji reliabilitas karena hasil dari nilai cronbach's alpha dan composite reliability lebih besar dari 0,6.

\section{Uji Koefisien Determinasi $\left(R^{2}\right)$}

Dalam suatu penelitian, koefisien determinasi digunakan untuk mengetahui adanya efek pengaruh dari variabel eksogen terhadap variabel endogen yang ada. Hasil koefisien determinasi $\left(R^{2}\right)$ dapat dilihat pada tabel 4 di bawah ini.

Tabel 6. Hasil Uji Koefisien Determinasi $\left(R^{2}\right)$

\begin{tabular}{|c|c|c|}
\hline Variabel & $\boldsymbol{R}$-Square & $\boldsymbol{R}$-Square Adjusted \\
\hline Financial Satisfaction & 0,554 & 0,550 \\
\hline
\end{tabular}

Pada tabel 6. dapat dilihat bahwa hasil dari koefisien determinasi sebesar 0,554 yang berarti bahwa 55,4\% dari variabel dependen yaitu financial satisfaction dapat dijelaskan olehh variabel independen pada penelitian ini dan sisanya sebesar sebesar 44,6\% dijelaskan oleh variabel lain diluar dari model penelitian yang diteliti. Nilai koefisien determinasi yang diperoleh tergolong moderate. 


\section{4. $\quad$ Uji Effect Size $\left(f^{2}\right)$}

Pengujian effect size $\left(f^{2}\right)$ dalam penelitian ini bertujuan untuk mengetahui dan mengukur seberapa besar pengaruh dari variabel indepenen terhadap model struktural yang ada. Hasil dari uji effect size dapat dilihat pada tabel 5 di bawah ini.

Tabel 7. Hasil Uji Effect Size $\left(\boldsymbol{f}^{2}\right)$

\begin{tabular}{|c|c|}
\hline Variabel & Financial Satisfaction \\
\hline Financial Attitude & 0,127 \\
\hline Financial Literacy & 0,414 \\
\hline Financial Satisfaction & - \\
\hline
\end{tabular}

Pada tabel 7. dapat dilihat bahwa nilai effect size $\left(f^{2}\right)$ pada variabel financial attitude mengalami efek perubahan yang kecil atau lemah yaitu sebesar 0,127. Sementara untuk variabel financial literacy mengalami efek perubahan yang besar atau kuat yaitu sebesar 0,414.

\section{Uji Predictive Relevance $\left(Q^{2}\right)$}

Pengujian predictive relevance digunakan untuk melihat seberapa baik suatu konstruk variabel-variabel yang ada dalam penelitian ini. Hasil pengujian predictive relevance akan ditampilkan dalam tabel 4.12 dibawah ini.

Tabel 8. Hasil Uji Predictive Relevance $\left(Q^{2}\right)$

\begin{tabular}{|c|c|}
\hline Variabel & $\boldsymbol{Q}^{\mathbf{2}}$ \\
\hline Financial Satisfaction & 0,277 \\
\hline
\end{tabular}

Pada tabel 8. menunjukkan bahwa variabel financial satisfaction memiliki nilai $Q^{2}$ sebesar 0,277 yang berarti niali $Q^{2}$ financial satisfaction lebih besar dari 0 , sehingga dapat disimpulkan financial satisfaction bersifat relevan dan dapat dipakai untuk mengukur suatu model penelitian yang sebelumnya telah dibentuk.

\section{Uji Goodness of Fit (GoF)}

Pengujian goodness of fit (GoF) dilakukan secara manual dengan menggunakan pengukuran sederhana yang digunakan untuk menguji dan mengevaluasi kelayakan model dalam penelitian ini. Hasil perhitungan goodness of fit $(\mathrm{GoF})$ dalam penelitian ini mempunyai tingkat kelayakan model penelitian sebesar 0,536 yang tergolong besar.

\section{Uji Hipotesis}

Pengujian hipotesis pada penelitian ini dilakukan untuk membuktikan apakah hipotesis yang diberikan dapat diterima atau ditolak. Garson (2016) mengatakan bahwa pengujian hipotesis penelitian yang menggunakan PLS-SEM dilakukan dengan melihat nilai t-statistik. Hipotesis penelitian dikatakan tidak ditolak apabila nilai t-statistik lebih besar dari 1,96 atau nilai $p$-values lebih kecil dari alpha 0,05 . Hasil pengujian hipotesis tertera pada Tabel 7 berikut ini. 
Tabel 9. Hasil Uji Hipotesis

\begin{tabular}{|c|c|c|c|}
\hline & $\begin{array}{c}\text { Original } \\
\text { Sample }(\mathbf{O})\end{array}$ & $\begin{array}{c}\text { T Statistics } \\
(|\mathbf{O} / \mathbf{S T D E V}|)\end{array}$ & P Values \\
\hline $\begin{array}{l}\text { Financial Attitude -> } \\
\text { Financial Satisfaction }\end{array}$ & 0,294 & 4,240 & 0,000 \\
\hline $\begin{array}{l}\text { Financial Literacy -> } \\
\text { Financial Satisfaction }\end{array}$ & 0,532 & 8,012 & 0,000 \\
\hline
\end{tabular}

Berdasarkan tabel 7 di atas, dapat disimpulkan bahwa hasil dari uji hipotesis financial attitude dan financial literacy memiliki pengaruh positif dan signifikan terhadap financial satisfaction karena telah memenuhi kriteria pengujian hipotesis.

\section{DISKUSI}

\section{Pengaruh Financial Literacy terhadap Financial Satisfaction}

Hasil penelitian ini menunjukkan adanya pengaruh positif dan signifikan financial literacy terhadap financial satisfaction. Salah satu indikator financial literacy yang mempengaruhi financial literacy adalah pernyataan mengenai pemahaman servis atau layananlayanan akan uang elektronik. Seseorang yang memiliki pemahaman akan konsep keuangan bertujuan untuk dapat mengambil keputusan dengan tepat.

Hasil penelitian ini sejalan dengan penelitian yang dilakukan oleh Sabri (2011) yang mengungkapkan adanya pengaruh positif antara financial literacy terhadap financial satisfaction. Seseorang yang memiliki pemahaman financial literacy yang baik maka akan semakin tinggi juga financial satisfaction yang dimiliki seseorang.

\section{Pengaruh Financial Attitude terhadap Financial Satisfaction}

Berdasarkan hasil analisis data pada penelitian ini, menunjukkan bahwa financial attitude menunjukkan adanya pengaruh positif dan signifikan terhadap financial satisfaction. Salah satu indikator financial attitude yang mempengaruhi financial satisfaction adalah pernyataan mengenai solusi dalam hal melakukan pembayaran cashless. Hal ini dapat terjadi karena seorang individu akan merasa puas dalam melakukan sesuatu jika seseorang menggunakan uang dengan bijak sehingga seseorang memiliki finansial yang dapat meningkatkan kualitas hidupnya dan juga financial satisfaction.

Hasil pengujian yang dilakukan pada penelitian ini sesuai dengan penelitian yang dilakukan oleh Chandra dan Memarista (2015) menyatakan bahwa financial attitude memiliki pengaruh positif dan signifikan terhadap financial satisfaction.

\section{PENUTUP}

Beradasarkan hasil analisis pada uji statistik dan uji hipotesis, maka dapat disimpulkan sebagai berikut :

1. Financial literacy memiliki pengaruh positif dan signifikan terhadap financial satisfaction pada pengguna Go-Pay di Jakarta Barat.

2. Financial attitude memiliki pengaruh positif dan signifikan terhadap financial satisfaction pada pengguna Go-Pay di Jakarta Barat. 
Terkait dengan keterbatasan dan hasil penelitian ini, maka akan diberikan beberapa saran yang dapat diuraikan sebagai berikut :

a) Bagi peneliti selanjutnya disarankan untuk menambahkan jumlah pengambilan sampel, jumlah indikator, dan variabel-variabel eksogen lainnya yang dapat mempengaruhi financial satisfaction sehingga hasil penelitian yang diperoleh bisa semakin lebih baik lagi dan bermanfaat untuk berbagai pihak.

b) Penyebaran kuisioner dapat disebarkan lebih meluas lagi jangkaunnya tidak hanya wilayah Jakarta Barat saja dan dapat menambahkan jumlah responden untuk penelitian selanjutnya.

c) Pembahasan mengenai ruang lingkup dalam penelitian ini perlu diperluas lagi, tidak hanya terbatas pada financial satisfaction pada pengguna Go-Pay yang berdomisili di Jakarta Barat saja.

\section{DAFTAR PUSTAKA}

Ajzen, I. (1985). From intentions to actions: A theory of planned behavior. In J. Kuhl \& J. Beckman (Eds.), Action-control: From cognition to behavior (pp. 11- 39). Heidelberg, Germany: Springer.

Ajzen, I. (2005). Attitudes, Personality and Behavior, (2ndedition), Berkshire, UK: Open University Press-McGraw Hill Education.

Arifin, A. Z. (2018). Influence Factors toward Financial Satisfaction with Financial Behavior as Intervening Variable on Jakarta Area Workforce. XXI(1), 90-103.

Chandra, J. W., \& Memarista, G. (2015). Factors Affecting Financial Satisfaction on Students of Kristen Petra University. Finesta, 3(2), 1-6.

Garman,E.T., and Forque, R.E. (2010). Personal Finance: International Edition, Canada: South WesterenCengageLearning.

Garson, G. D. (2016). Partial Least Square S (PLS - SEM) - Regression and Structural Equation Models. In Politeness and Audience Response in Chinese-English Subtitling. https://doi.org/10.3726/978-3-0353-0280-6/8

Henager, Robin, \& Sophia T. Anong. (2014). Financial Education, Financial Literacy, and Financial Satisfaction. American Council on Consumer Interests.

Hira, T. K., \& Mugenda, O. M. (1998). Predictors of financial satisfaction: Differences between retirees and non-retirees. Journal of Financial Counseling and Planning, 9(2), 75.

Huston, S. J. (2010). Measuring financial literacy. Journal of consumer affairs, 44(2), 296-316.

Jodi, L.P. \& Phyllis, J.J. (1998). The impact of financial attitude and knowledge on financial management and satisfaction of recently married individuals. Association for Financial Counselling and Planning 9(2).

Pankow, D. (2012). Financial Values, Attitudes, and Goals. Family Economic Specialist, NDSU

Praag, B., \& Carbonell, A.F. (2002). Life satisfaction differences between workers and nonworkers-the value of participation per se (No. 02-018/3). Tinbergen Institute discussion paper.

Sabri, M. F. F. (2011). Pathways to financial success: Determinants of financial literacy and financial well-being among young adults. https://doi.org/10.31274/etd-180810-1956

Sahi, S. K. (2013). Demographic And Socio-economic Determinants Of Financial Satisfaction. International Journal of Social Economics, 40(2), 127-150. 